Article

\title{
Social Sustainability in Business Organizations: A Research Agenda
}

\author{
Merlina Missimer *(-) and Patricia Lagun Mesquita
}

check for

updates

Citation: Missimer, M.; Mesquita, P.L. Social Sustainability in Business

Organizations: A Research Agenda. Sustainability 2022, 14, 2608.

https://doi.org/10.3390/su14052608

Academic Editor: Ioannis Nikolaou

Received: 21 December 2021

Accepted: 19 February 2022

Published: 24 February 2022

Publisher's Note: MDPI stays neutral with regard to jurisdictional claims in published maps and institutional affiliations.

Copyright: (c) 2022 by the authors Licensee MDPI, Basel, Switzerland. This article is an open access article distributed under the terms and conditions of the Creative Commons Attribution (CC BY) license (https:// creativecommons.org/licenses/by/ $4.0 /)$.

\author{
Department of Strategic Sustainable Development, Blekinge Institute of Technology, 37141 Karlskrona, Sweden; \\ pdl@bth.se \\ * Correspondence: mis@bth.se
}

\begin{abstract}
Since the economic crisis in 2008, the world has seen a partly negative shift in social progress, highlighting that current economic models and practices do not guarantee long-lasting societal and human wellbeing. Economic models and business practices are deeply intertwined; thus, businesses play a major role in the advancement of social sustainability, and academic research can offer support in navigating the complexity of this issue. However, social sustainability tends to be under-researched. This article summarizes the discussion in general business management, product development, and supply-chain management, and from this suggest a research agenda to help in guiding systematic change in business organizations towards social sustainability. The article identifies ten main challenges and offers five recommendations to move the field forward, namely, a more explicit engagement with and discussion of social systems-science based ideas, and a more explicit determination as a field to converge on key pieces leading towards a clearer definition of the concept. Lastly, it recommends that research needs to focus on how to overcome fragmented organizational structures, how to achieve true integration into existing processes and tools, and how to support organizations to become more dynamic in working with these issues.
\end{abstract}

Keywords: social sustainability; strategic sustainable development; research agenda; business; systems approaches

\section{Field Overview}

For decades, it has been clear that our ecosystems are unable to sustain society's current focus on economic growth and associated types and levels of consumption in the long term [1]. Additionally, since the economic crisis in 2008, we have seen a partly negative shift in social progress, and even some developed countries have experienced an increase in poverty and income inequality [2,3]. Essential aspects of well-functioning social systems such as trust, diversity, and common meaning appear to be undermined in many parts of the world [4-6], strengthening evidence that current economic models and practices do not guarantee long-lasting societal and human wellbeing. We thus need to address social challenges in connection with ecological challenges, and to ensure that both the ecological system and the social fabric remain healthy in order to achieve full sustainability. As many of our systems are fundamentally grounded in unsustainable premises, progress toward sustainability therefore requires entire systems change $[7,8]$.

Current economic models and business practices are deeply intertwined; thus businesses play a major role in promoting or hindering (social) sustainability. Systematic knowledge creation in academia on the other hand can support businesses in navigating the complexity of (social) sustainability. However, social sustainability tends to be neglected in academic discourse and in practice [9-14]. The literature is generally limited [13,15], but the lack of a clear theoretical concept $[9,13]$, of a clear understanding of how to interpret it in practice [16], and of clear indicators [17] are discussed as major challenges. An overview of different social sustainability definitions is provided in Missimer [18], who concluded 
that, although some authors elaborate their own definitions (usually in a participatory process in community planning), many other authors, rather than providing a definition, create lists of themes or aspects relating to human and social issues that should be included in considerations of social sustainability. These lists can be as broad and short as 4 themes or as specific and long as 43 themes [18].

Boström [19] describes social sustainability as including both substantive and procedural aspects. By substantive, he means the what that is required to achieve social sustainability, whereas by procedural aspects, he means how to achieve it. According to him, "aspects overlap, and it is not always easy to distinguish between substantive and procedural aspects, as they may reinforce one another" [19] (p. 6).

Boyer et al. [20] classifies the current ideas about the social pillar in what they name five approaches to social sustainability. According to the authors, social sustainability has been approached as (1) a stand-alone objective or third pillar; (2) a constraint upon economic and environmental imperatives; (3) a precondition for thriving economic and environmental systems or social capital; (4) a causal mechanism of environmental and economic change; and (5) a fully integrated, locally rooted, and process-oriented approach to sustainability. The fifth approach is considered by Boyer et al. [20] to be the most suitable, as it is claimed to provide a more systemic and integrated view of sustainability simultaneously be grounded in local knowledge and experience. Using Boström's typology [19] of substantive (what) versus procedural (how), the fifth approach seems to talk more about the how than the what. A focus on the social change that is needed for sustainability to occur is certainly important, but the question of what social sustainability is remains unanswered in this approach and it remains unclear how social fabric is undermined (akin to how unsustainable practices undermine ecological systems).

Since sustainability of the ecological and the social systems are global and societal systems properties, individual companies or products cannot be deemed sustainable unless sustainability is achieved in those larger systems of which they are part and on which they are dependent [21]. However, without this perspective and an agreed-upon definition, social sustainability in practice often ends up as a "laundry list" [22] or "black bin" [23], where organizations place all human, social, and/or indefinable elements of sustainability. Within the context of business organizations, various fields touch on these ideas related to social sustainability. Below we build on our own previous work, and summarize the discussion and status quo in three main fields: general business management, product development, and the supply chain field. Both authors have focused their academic work on social sustainability within organizational contexts for over a decade $[5,6,24-31]$, having conducted both empirical work and extensive literature reviews. From this, we present in the following section a research agenda that we believe is necessary to move the field of social sustainability in business organizations forward, and it is intended to be an invitation and call to action to fellow researchers in the field, so that academic research could help guide systematic change in business organizations toward social sustainability.

\subsection{Social Sustainability in Business Management}

A range of terms is used to cover social sustainability in business management, including corporate citizenship, corporate sustainability (CS), and corporate social responsibility (CSR) [32,33], the latter often being used as the overarching term for the social dimension (although it sometimes also includes responsibility for environmental issues). In addition, a myriad of tools building on these theoretical approaches exist to help business work with and account for the social dimension, such as Social Return on Investment, ESG accounting, and ISO 26000. While none of the terms comes with a clear definition that addresses the what of full social sustainability [34,35], Nijhof et al. [36] state that CSR usually implies the incorporation of issues such as human rights, labor rights, consumer protection, and fighting corruption in corporate practices. Two important paradigms are the core of the discussion in the field: the stakeholder [37] and the responsibility paradigms [38]. Bolton et al. [32] criticize the stakeholder approach for usually focusing on a particular set of 
stakeholders (e.g., external over internal), not taking into account the unequal possibility among stakeholders to voice their concerns, and for leading to a fire-fighting approach steered by corporate reputation rather than a holistic and strategic approach. Moratis and Brandt [39] add that stakeholders are often consulted but not included in decision making. Connected to stakeholder theory is a discussion of the role of business in society, namely, to whom or what organizations are responsible [38,40]. Nijhof et al. [36] describe corporate responsibility as a learning process in which organizations determine how far to extend their responsibilities and available resources. Multiple models exist [41-43] that usually move from a narrow focus in terms of what and to whom (such as own employees only) towards an expanded focus. Responsibility then includes stakeholder networks, and is based on the awareness of the effects of complex interdependencies between the company and other actors, which are often unseen and unpredictable [38,40,42]. Companies want to do well by doing good, and stakeholders are seen as partners in "changing the game" to create system-level innovation [41]. In Mesquita and Missimer [24], there is also evidence of this movement. Corporate sustainability emerged as a connected but distinct concept to CSR, emphasizing the embeddedness of firms in socioecological systems and the interdependencies that this generates $[38,44,45]$. As organizations become more systemic and systematic in their perspective, goals are more likely to be derived from a scientific systems understanding [38,45,46], and to align with the goals of larger systems flourishing [45]. However, Meuer et al. [34] indicate the importance of unpacking the scope of these efforts and explicitly defining what is meant by sustainability, as firms are still randomly selecting issues and only connect them to sustainability as an afterthought. Landrum [45], with more focus on the ecological side, further stresses that science-based sustainability and strategic planning are the fundamental paradigm shift needed for businesses to develop strong sustainability approaches, guided by what is needed for sustainability in the world. Weak sustainability, the dominant paradigm in business organizations, tends to focus on incremental improvements that does not lead to sustainability: "Strong sustainability is outside current frames of reference for business and industry and is not part of the understanding or reality in defining sustainability; that is, strong sustainability is not part of the conceptual sustainability frame in firm-level models. These restricted parameters defining sustainability confine the array of corporate actions and behaviors necessary to achieve sustainability" (ibid, p. 305).

To be successful, both ecological and social sustainability have to be integrated at all levels of the organization [47]. Full integration means that "elements of organizational strategy cascade down to all levels and, thus, create a fit among organizational objectives, targets, and processes" [48], and that the coordination of departments at the operational level is key. However, organizational structures and processes for integration continue to be under-researched [49-52] and are also often not required in practice, e.g., embedding sustainability within a company's structure is currently not required by the GRI or SDG business disclosures [53]. Even fewer studies exist using empirical data to follow up on the implementation of social sustainability or on the organization and integration of social sustainability work in general [24,25]. Wang et al. [37], in their editorial to the Academy of Management Review, call for a descriptive research agenda that investigates how and why corporations actually engage in social sustainability (framed as corporate social responsibility) to only then derive a better understanding of how they should engage in social sustainability.

\subsection{Social Sustainability in Product Development}

The production and consumption of products greatly contribute to the ecological and social problems that we face today. Therefore, product development companies can play a key role in society's transition towards sustainability [54]. Efforts to integrate sustainability in product development organizations have largely focused on ecological aspects [21,55] and the social dimension has mostly been neglected [56], mirroring the neglect in the general sustainable development field. The lack of agreement on how to define social 
sustainability in general impedes companies from assessing how they and their products contribute to a socially sustainable society. Social lifecycle assessment (Social LCA) methods are one example of the implications of loosely defined social sustainability goals: after nearly 20 years of development, Social LCA still lacks a unifying framework that could allow for the further development of the field and provide more robust decision support for product development organizations [57-61]. Schulte and Hallstedt [62] and Watz and Hallstedt [63] all define sustainable product development as product development that supports society's transition toward sustainability, evidencing that the focus is moving toward positioning also this field in a larger systems perspective and Dyllick and Rost [61] urge to include social concerns alongside the ecological ones in this perspective. There is however little evidence that even on the ecological side companies are setting science-based goals [46], although some progress has been made [64-66].

In terms of integration, anchoring sustainability also into product development and organizational processes horizontally and vertically is critical, rather than developing standalone sustainability tools and methods $[67,68]$. In addition, a broader business system perspective is needed, and not just a narrow focus on product development itself $[67,69]$. New research should try to propose strategies that consider this larger focus [70] and have a more explicit focus on the strategic implementation of sustainable product design [71], than to focus on theoretically correct and detailed support. Lastly, organizational complexities play a significant role in integrations efforts. Internal barriers and enablers need to be understood to allow for the successful integration of sustainability considerations [67,72].

Empirical evidence of social sustainability integration in organizations, specifically in product development, is also scarce. A review of the literature leads to few results and little insight into how to integrate social sustainability in product development or how product development organizations systematically work with social issues. Schulte and Hallstedt [62] found that companies struggle with integrating social sustainability all the way into product development, and Watz and Hallstedt [63] found that only one out of seven case organizations had begun considering social aspects alongside ecological ones in the integration of sustainability requirements in the product development process. None of the studies explores why this is the case or what efforts currently exist to address the social dimension. In Mesquita and Missimer [24], we began filling this gap by studying three product development companies in detail, and answering the call of Wang et al. [37] for a descriptive research that investigates how and why corporations actually engage in social sustainability. In Mesquita and Missimer [25], we then propose how to engage in social sustainability work that could contribute to resolving issues on a global scale. We argue that the further development of theory relating to social sustainability integration in product development requires a finer understanding of the different types of social sustainability approaches than what we have today. Current stage models (e.g., typologies and maturity models) of corporate sustainability and sustainable product development are insufficiently sensitive to the specificity of ecological versus social sustainability and to the complex dynamics of socio-ecological systems [34]. This theoretical limitation hinders social sustainability goals to be pursued in balance with ecological ones and system innovation to be developed. A more careful conceptualization of approaches to social sustainability in product development organizations will help in improving our understanding of an organization's specific responses to different contextual stimuli and design effective interventions to support those organizations to move forward in their sustainability journey.

\subsection{Social Sustainability in Supply Chains}

A great challenge for social sustainability particularly is that social impacts tend to not be related to the nature of a specific product or production process, but are rather dependent on the conduct of the companies in the supply chain carrying out the processes $[73,74]$. At the same time, supplier sustainability is the top barrier for companies in their advancement to the next level of sustainability performance [75] and supply chain 
managers often struggle with the dynamic and complex nature of the chains. With the growing global attention and the impact that social sustainability issues such as child labor and poor working conditions have on leading firms' reputations, dependence on supplier sustainability specifically is increasingly considered a business risk [76]. Given pressure from stakeholders, organizations must sooner or later actively seek to achieve sustainable supply chains [77]. As a consequence, sustainable supply chain management is an emergent research field increasing in volume and maturity [78,79]. However, the literature points to some challenges.

First, there is a consensus on the lack of a holistic understanding of sustainability and to an unbalanced attention to environmental and economic issues when compared to social ones [80-82]. The little research that focuses on social sustainability often falls short in defining what is meant by it, signaling a need for researchers to clarify its meaning from the supply chain management perspective [76].

Second, there is too narrow a unit of analysis. Studies tend to solely focus on the plant or firm level and have a limited stakeholder perspective [80]. Only a small number of studies explicitly take a multitier perspective, i.e., first- and second-tier suppliers, and focal firms [76]. Supply chains are conceptually not even true chains, but rather supplier networks composing complex interactions and flows of material and information; thus, they are "dynamic, complex, and difficult to predict and control" [82]. Since the achievement of socially sustainable supply networks is not only linked to material flows, but also to knowledge and information flows, there is even a need to look beyond the network. This means changing the level of analysis to include stakeholders such as customers, regulators, standardization and certification actors, and local communities, and to allow for the measurement of value creation in that system [80]. As a deeper understanding of each network emerges from local contexts and through specific interactions between network members and relevant local stakeholders, it is useful to also understand the work by these other actors in relation to social sustainability in value networks.

In terms of working practice, this implies the need for a more dynamic approach to managing or more appropriately steering these networks. In the sustainable supplychain management literature, the importance of the development of dynamic capabilities is clearly highlighted $[77,83]$. Dynamic capabilities are defined as a firm's capacity to integrate, build, and reconfigure internal and external resources using organizational processes to respond to changes in the competitive environment, and to design new value creating strategies $[84,85]$. Conducting research on how to improve dynamic capabilities of supply networks on the basis of a deep understanding of their dynamism and complexity is cutting-edge in the field [86]. Two propositions for how to connect dynamic capabilities to sustainable supply chain management have been made $[77,87]$. However, both conclude that new theoretical lenses are needed to identify additional dynamic capabilities specifically regarding social sustainability.

Lastly, research has emphasized the 'what' of sustainable supply chain management rather than the 'how' [80]; as a result, there is a lack of practical support for how to implement and operationalize it [79]. As regards social sustainability, the majority of the papers focus on performance measurement followed by procurement decision-making and drivers influencing adoption of social sustainability. Approaches for integrating social sustainability in supply chains are so far mostly conceptual and prescriptive, "without going deeper into the realities of what goes on in practice" [76] (p. 530), and addressing the dynamic complexity of the issue in practice.

\section{Synthesis and the Research Agenda Moving Forward}

The literature from the three interconnected fields above converges on the challenges of the field of social sustainability in business organizations:

- Poor definition of social sustainability [34,35,57-61,76,80-82]: Much of the literature in the field shies away from precisely defining the concept of social sustainability. This lack of definition becomes a circular problem that leads to less and less clarity, 
as the lack of a definition makes the field fuzzy, and leads to issues such as the ones below. Although we acknowledge the impossibility of agreeing on a single vision for a socially sustainable society, scholars can and should attempt more convergence on some key pieces, and not shy away from this discussion to counteract the negative consequences below that arise from this lack of clarity.

- $\quad$ Picking (sometimes seemingly random) issues [32,34,39,76,80]: Poor definition leads to random inclusion of issues and often context-specificness or subjectivity in issue inclusion, which complicates achieving convergence on what social sustainability is, as scholars build on each other's work. The first two problems enable organizations in claiming that they are progressing in the field of social sustainability when they are tackling issues individually or not at all. Since social problems are often highly interrelated, tackling them in isolation may lead to worse social situations in the long run.

- Lack of systems and the science-based understanding of social sustainability and goal-setting [38,45,46,64-67,69,70]: While this challenge is also pointed out in the ecological sustainability field, it is especially prevalent in the social sustainability field, because systems-based approaches remain rare and even contentious. However, without a systematic understanding of the larger challenge, it is again difficult to claim that we are advancing in the field, and goals remain ad hoc and too narrow, and are rarely strategic.

- Lack of ability to deal with (conflicts and tradeoffs between) issues strategically [88,89]: the lack of clarity also leads to an inability to strategically decide on which issues to focus and how to deal with potential conflicts, potentially creating unnecessary competition between issues over scarce resources such as time and money. In the worst case, this means that a particular issue is selected on the basis of its proponents being the loudest rather than because it is most material to the organization in the larger picture.

- $\quad$ Lack of clarity how to best use existing tools [34,57-61,80]: The same challenge as with issues applies to selection of support tools in social sustainability work. There is no shortage of tools that help in addressing social sustainability issues. However, without a general, systematic, and systemic understanding of the challenge, it is difficult to assess which tool is right for which purpose, and how they could be optimally combined to achieve the greatest results.

- Limited research on structures and processes for implementation and integration [49-52]: The academic body of knowledge regarding actual implementation of social sustainability is scare. There is unfortunately not much systematic understanding of structures and processes that transforms ideas into tangible outputs.

- $\quad$ Lack of empirical data and support informed by the realities of practice $[24,25,37,76,79,80]$ : Much of the existing research is more theoretical, rather than a systematic studying of empirical data. Even studies that focus on support design are criticized for not being practice-based enough.

- $\quad$ Fragmented organizational structure hinderance to collaboration on these issues [24,26]: The little we know from existing research is that often the organizational structure itself is an obstacle to achieving social sustainability goals. As these goals often go across departments and focus areas, collaboration is key in achieving results. Due to the rigidity of existing organization structures, this is often not possible effectively. When organizational structures are in place to deal with sustainability goals, they often embrace mostly ecological aspects, possibly due to a narrow definition of sustainability, and social aspects are dealt with by a range of departments, e.g., human resources, purchasing, and environmental, health and safety (EHS) without a unifying strategy to align the work.

- Lack of true integration rather than stand-alone and add-on approaches and tools $[47,48,67,68]:$ The above challenges then lead to initiatives being added on to the existing processes and structures rather than being truly integrated. This leads 
to social sustainability issues being yet another set of issues to consider on a very long list and also often misses possible synergies or true transformations.

- More dynamic processes of working with these issues lacking [77,83-87,90]: Lastly, even in practice, organizations are missing the required ability to be dynamic and act quickly given the set of complex and fast changing issues that social sustainability poses.

The challenges identified above are not unique to the business context. In municipal planning, for example, the lack of a clear definition, the resulting inability to choose issues and support tools, and organizational structures are real challenges. Consequently, even though large parts of a municipal administration's work are social sustainability work, it does not seem easy to structure the efforts and coordinate the work [26]. This implies that there is not much to glean from other research fields and that additional and original research is required. The above lays out a fairly straightforward but ambitious research agenda.

\subsection{Towards a Clearer Definition of Social Sustainability Based on a (Systems) Science Understanding and Deriving Goals Thereof}

A more explicit engagement with and discussion of social-system-science-based ideas. In the recent literature, there is a push for science-based sustainability goals [46] and for organizations to shift from an insular and inside-out to a systemic and outside-in perspective, which creates the possibility for businesses to contribute to global sustainability $[43,45,61]$. Because sustainability is a systems property, individual companies or products cannot be deemed sustainable unless the systems of they are part are [23]. These discussions often, however, focus more on ecological systems, leaving science-based social sustainability goals unexplored. CSR scholars have concentrated on other research themes, such as the moral responsibilities of organizations and the norms that guide business behavior [34,38,91]. It is often even argued that science-based social sustainability goals are not possible. However, social-system-based approaches have come a long way and have much to offer in understanding dynamics of social systems and the goals we might strive for if we wanted to aim for a socially sustainable society.

A system's approach would move social sustainability thinking from focusing on individual and isolated problems to structural and societal problems (some work already focuses on structural societal challenges but usually on isolated issues). A systems science approach to social sustainability takes into account that social sustainability issues are inextricably interlinked; it is, therefore, hard to predict what could happen if the whole system is not considered when designing solutions. This also implies thinking about the nesting and inter-linkages of various (sub-) systems, such as nations, communities and organizations across value chains.

A system-science-based approach would also provide a more structured way to explore the most upstream causes. When exploring problems in their interconnections with other systems it may be possible to arrive at new understanding of drivers of some of the challenges we see today and to reveal causes that are more upstream. This increased understanding can also lead to solutions at the level of systems rather than the usual focus on alleviating downstream symptoms and provide a structured way to identify connections between smaller scale practices and norms to troublesome structures in wider systems. We could then identify social sustainability goals on the basis of this understanding and assure that our goals aim to systematically eradicate current issues.

A more explicit determination as a field to converge on key pieces leading towards a clearer definition of the concept (while leaving room for a diversity of ideas and approaches). A lack of scientific clarity from academia also impacts the sustainability agenda in organizations. If academia does not have any clarity, why should businesses? If the academic community would move towards a system-science-based understanding, organizations could then no longer cherry-pick which issues to address, and would instead be required to also apply a holistic and inclusive perspective. A clear example of this problem 
is found in corporate efforts to report progress towards the Sustainable Development Goals (SDGs). Because they are societal goals, companies often lack a way to understand, identify, and address their contribution to the problems that the goals are targeting and even map the interconnection between the different goals. In the end, they often pick the goals that resonate the most with their business objectives, rather than systematically and strategically working with them as a whole [92,93]. Recognizing the interconnectedness of social problems opens up the possibility for organizations to see how their organizational practices might reinforce these larger troublesome structures. It would likely also allow for organizations to deal better with trade-offs and to plan strategically, not the least how to best employ existing tools in the field. If organizations were to design their social sustainability strategies from this understanding, chances are that solutions would require a more robust and encompassing stakeholder engagement than we see today. Until a systemic perspective is adopted, however, improvements are likely to be limited to incremental, local and short-term.

To be transparent, we have been working on developing such a systems-sciencebased definition of social sustainability for years now within the Framework for Strategic Sustainable Development [5,6]. The approach was specifically built on a complex adaptive systems understanding of human social systems and the mechanisms that destroy this social web. By reframing the mechanisms of destruction as design constraints and declaring these as success, the approach can support organizations at all levels to strategically contribute to social sustainability. Such a definition differs from goals such as the SDGs, as it aims to define what social sustainability is at a principled level whereas SDGs are important milestones to be achieved in the progress towards sustainability (also called sustainable development), but do not cover all possible systemic sustainability challenges nor does their achievement lead to full sustainability. Stakeholder engagement processes are still vital for the development of collaboration with a wide range of actors, but when framed by a clear high-level definition of success, such processes can be better facilitated and coordinated. However, this is only one approach. Others are possible and need to be developed, so that we can truly move the needle on social sustainability. In the end the scientific definition and science-based goals are only relevant because they enable strategic work at an organizational level, where actual social sustainability impacts occur.

\subsection{Practice-Based Research on Sustainability Integration: Structures and Processes with a Focus on Dynamically Overcoming Systemic Challenges}

In order to contribute to real change, academic work needs to be as connected to actual organizational practice as possible, and to support true integration. This means academia needs to attempt to produce even more practice-based research, be it as an observer or as action research. The focus should be on both understanding current practices as there is a lack of empirical data regarding real-world implementation and on supporting the design of better processes, structures and practices together with organizations. Collaboration on this is important, as even design-focused research in this area has been criticized for being too theoretical. Three particular practice-based research focus areas emerge.

How to overcome fragmented organizational structures. We have evidence that organizational structure in itself is often a challenge to achieving social sustainability progress. The hierarchical way of structuring ourselves in organizations hinders headway on issues that are cross-cutting and require collaboration. It is, therefore, essential for organizations and researchers to look into ways of overcoming this challenge, be it through organizational restructuring or cross-cutting structures. Our own work shows that organizations that are most advanced in working with social sustainability have found a way of organizing that overcomes traditional hierarchies, and allows for more collaborative and strategic work in this area [24]. However, much more is needed. Organizational change in this regard is difficult and takes a long time; more focus needs to be put on understanding how this can be made to work better. 
A connected area of interest is how to achieve true integration into existing processes and tools. Social sustainability is often treated as an add-on to ecological sustainability and social sustainability issues are then forced to fit into existing approaches and tools without really taking complexity or particularities into account. This may look like integration, but in reality often only superficially addresses social issues. On the other end of the spectrum, social sustainability is treated as a totally separate issue, and tools to work with it are being added on to a long list of other existing tools to work with ecological sustainability, quality, etc. Neither of these are ideal. Instead, we need to find ways of integration or creating processes that allow for all actual goals to be met. Schulte and Hallstedt [65] claim that, for this to happen, changes in processes and support tools across all levels of decision making (strategic, tactical, and operational) are needed. However, much more research is needed.

Lastly, an important area of interest is how to support organizations to become more dynamic in their way of handling challenges such as social sustainability issues. While organizations know that the world is becoming more complex and dynamic, not just in regard to social sustainability issues, it is harder to adapt organizational structures and processes to become equally dynamic to match the challenge. More research focus is needed on supporting organizations in this transition and systematically testing and evaluating possible changes to assess whether they do lead to the desired result or are just a management fad.

\section{Concluding Remarks}

In their 2020 editorial to the Academy of Management Review, Wang et al. [37] called for an agenda that investigates how and why corporations actually engage in social sustainability (framed as corporate social responsibility), and then derive a better understanding of how they should engage in social sustainability. We build on this by suggesting specific areas of focus that need to be explored more from a practice-based perspective, and that the academic field can significantly contribute to through its rigorous and systematic approaches of gaining and creating knowledge. However, it is important that this occurs in combination with moving towards a clearer definition, and science-based goals, as there is no use of creating better integration and overcoming fragmentation if the goals are not strategic to pursue.

The COVID-19 pandemic and the measures taken to contain it have put a spotlight on existing social issues, set back socioeconomic development in many parts of the world, and have reversed progress towards the Sustainable Development Goals [94]. In addition to economic recovery, it is essential to rebuild and advance social sustainability to improve health and wellbeing equally across the globe. While action occurs at the business and political levels, academia has a role to play in supporting action to have scientific grounding and a long-term strategic perspective.

Author Contributions: Conceptualization, M.M. and P.L.M.; literature review, P.L.M. and M.M.; writing-original draft preparation, M.M. and P.L.M.; writing—review and editing, P.L.M. and M.M. All authors have read and agreed to the published version of the manuscript.

Funding: This research was funded by the Knowledge Foundation and the FUTURA Foundation, both in Sweden as well as the Blekinge Institute of Technology, Karlskrona, Sweden.

Institutional Review Board Statement: Not applicable.

Informed Consent Statement: Informed consent was obtained from all subjects involved in the study. Data Availability Statement: Not applicable.

Acknowledgments: Financial support from the Knowledge Foundation, the FUTURA Foundation, as well as the Blekinge Institute of Technology is gratefully acknowledged.

Conflicts of Interest: The authors declare no conflict of interest. The funders had no role in the design of the study; in the collection, analyses, or interpretation of data; in the writing of the manuscript, or in the decision to publish the results. 


\section{References}

1. Reid, W.V.; Watson, R.; Zakri, A.H.; Cropper, A.; Mooney, H. Ecosystems and Human Well-Being: Biodiversity Synthesis; Island Press: Washington, DC, USA, 2005.

2. Cobb, J.A.; Stevens, F.G. These Unequal States: Corporate Organization and Income Inequality in the United States. Adm. Sci. Q. 2017, 62, 304-340. [CrossRef]

3. Jiang, L.; Probst, T.M. The Rich Get Richer and the Poor Get Poorer: Country-and State-Level Income Inequality Moderates the Job Insecurity-Burnout Relationship. J. Appl. Psychol. 2017, 102, 672. [CrossRef]

4. Edelman, R. Edelman 2020 Edelman Trust Barometer; 2020. Available online: https://www.edelman.com/trust/2020-trustbarometer (accessed on 15 December 2021).

5. Missimer, M.; Robèrt, K.H.; Broman, G. A Strategic Approach to Social Sustainability-Part 1: Exploring the Social System. J. Clean. Prod. 2017, 140, 32-41. [CrossRef]

6. Missimer, M.; Robèrt, K.H.; Broman, G. A Strategic Approach to Social Sustainability-Part 2: A Principle-Based Definition. J. Clean. Prod. 2017, 140, 42-52. [CrossRef]

7. Draper, S. Creating the Big Shift: System Innovation for Sustainability. Forum for the Future. 2013. Available online: https: / / www.forumforthefuture.org/Handlers / Download.ashx?IDMF=5092e413-2f97-43bf-bd7f-9f770d213ce8 (accessed on 15 December 2021)

8. Vezzoli, C.; Kohtala, C.; Srinivasan, A.; Xin, L.; Fusakul, M.; Sateesh, D.; Diehl, J.C. Product-Service System Design for Sustainability; Greenleaf Publishing: Sheffield, UK, 2014.

9. Littig, B.; Griessler, E. Social Sustainability: A Catchword between Political Pragmatism and Social Theory. Int. J. Sustain. Dev. 2005, 8, 65. [CrossRef]

10. Partridge, E. 'Social Sustainability': A Useful Theoretical Framework. In Proceedings of the Australasian Political Science Association Annual Conference 2005, Dunedin, New Zealand, 28-30 September 2005.

11. Kunz, J. Social Sustainability and Community Involvement in Urban Planning; University of Tampere: Tampere, Finland, $2006 ;$ p. 118.

12. Cuthill, M. Strengthening the "Social" in Sustainable Development: Developing a Conceptual Framework for Social Sustainability in a Rapid Urban Growth Region in Australia. Sustain. Dev. 2010, 18, 362-373. [CrossRef]

13. Dempsey, N.; Bramley, G.; Power, S.; Brown, C. The Social Dimension of Sustainable Development: Defining Urban Social Sustainability. Sustain. Dev. 2011, 19, 289-300. [CrossRef]

14. Vallance, S.; Perkins, H.C.; Dixon, J.E. What Is Social Sustainability? A Clarification of Concepts. Geoforum 2011, 42, 342-348. [CrossRef]

15. Colantonio, A.; Dixon, T.; Ganser, R.; Carpenter, J.; Ngombe, A. Measuring Socially Sustainable Urban Regeneration in Europe; EIB Final Report; Oxford Institute for Sustainable Development (OISD), Oxford Brookes University: Oxford, UK, 2009.

16. Weingaertner, C.; Moberg, A. Exploring Social Sustainability: Learning from Perspectives on Urban Development and Companies and Products. Sustain. Dev. 2014, 22, 122-133. [CrossRef]

17. Omann, I.; Spangenberg, J.H. Assessing Social Sustainability The Social Dimension of Sustainability in a Socio-Economic Scenario In Proceedings of the Biennial Conference of the International Society for Ecological Economics, Sousse, Tunisia, 6-9 March 2002; Volume 7.

18. Missimer, M. Social Sustainability within the Framework for Strategic Sustainable Development; Blekinge Institute of Technology: Kalrskrona, Sweden, 2015.

19. Boström, M. A Missing Pillar? Challenges in Theorizing and Practicing Social Sustainability: Introduction to the Special Issue. Sustain. Sci. 2012, 8, 3-14. [CrossRef]

20. Boyer, R.H.; Peterson, N.D.; Arora, P.; Caldwell, K. Five Approaches to Social Sustainability and an Integrated Way Forward. Sustainability 2016, 8, 878. [CrossRef]

21. Gaziulusoy, A.I.; Brezet, H. Design for System Innovations and Transitions: A Conceptual Framework Integrating Insights from Sustainablity Science and Theories of System Innovations and Transitions. J. Clean. Prod. 2015, 108, 558-568. [CrossRef]

22. McMahon, M.; Bhamra, T. Social Sustainability in Design: Moving the Discussions Forward. Des. J. 2015, 18, 367-391. [CrossRef]

23. Findeli, A. Sustainable Design: A Critique of the Current Tripolar Model. Des. J. 2008, 11, 301-322. [CrossRef]

24. Mesquita, P.L.; Missimer, M. Social Sustainability Work in Product Development Organizations: An Empirical Study of Three Sweden-Based Companies. Sustainability 2021, 13, 1986. [CrossRef]

25. Mesquita, P.L.; Missimer, M. A Typology of Approaches to Social Sustainability Integration in Product Development Organizations. 2021. Available online: https://www.diva-portal.org/smash/get/diva2:1539618/FULLTEXT01.pdf (accessed on 15 December 2021).

26. Wälitalo, L.; Missimer, M. The Organization of Social Sustainability Work in Swedish Eco-Municipalities. Sustainability 2022. accepted.

27. Mesquita, P.L.; Broman, G.; Hallstedt, S. Analyzing Social LCA Approaches through the Lens of Strategic Sustainable Development. In Proceedings of the XXVII International Society for Professional Innovation Management (ISPIM) Innovation Conference, Porto, Portugal, 19-22 June 2016.

28. Gould, R.; Missimer, M.; Mesquita, P.L. Using Social Sustainability Principles to Analyse Activities of the Extraction Lifecycle Phase: Learnings from Designing Support for Concept Selection. J. Clean. Prod. 2017, 140, 267-276. [CrossRef] 
29. Mesquita, P.L.; Hallstedt, S.; Broman, G. An Introductory Approach to Concretize Social Sustainability for Sustainable Manufacturing. In Proceedings of the Eleventh International Symposium on Tools and Methods of Competitive Engineering (TMCE 2016), Aix-en-Provence, France, 9-13 May 2016.

30. Missimer, M.; Robèrt, K.-H.; Broman, G.; Sverdrup, H. Exploring the Possibility of a Systematic and Generic Approach to Social Sustainability. J. Clean. Prod. 2010, 18, 1107-1112. [CrossRef]

31. Missimer, M.; Robèrt, K.H.; Broman, G. A Systems Perspective on ISO 26000. In Proceedings of the 2nd International Symposium "SYSTEMS THINKING FOR A SUSTAINABLE ECONOMY. Advancements in Economic and Managerial Theory and Practice", Rome, Italy, 23-24 January 2014.

32. Bolton, S.C.; Kim, R.C.; O'Gorman, K.D. Corporate Social Responsibility as a Dynamic Internal Organizational Process: A Case Study. J. Bus. Ethics 2011, 101, 61-74. [CrossRef]

33. Klettner, A.; Clarke, T.; Boersma, M. The Governance of Corporate Sustainability: Empirical Insights into the Development, Leadership and Implementation of Responsible Business Strategy. J. Bus. Ethics 2014, 122, 145-165. [CrossRef]

34. Meuer, J.; Koelbel, J.; Hoffmann, V.H. On the Nature of Corporate Sustainability. Organ. Environ. 2020, 33, 319-341. [CrossRef]

35. Taneja, S.S.; Taneja, P.K.; Gupta, R.K. Researches in Corporate Social Responsibility: A Review of Shifting Focus, Paradigms, and Methodologies. J. Bus. Ethics 2011, 101, 343-364. [CrossRef]

36. Nijhof, A.; De Bruijn, T.; Fisscher, O.; Jonker, J.; Karssing, E.; Schoemaker, M. Learning to Be Responsible: Developing Competences for Organization-Wide CSR. In The Challenge of Organising and Implementing Corporate Social Responsibility; Palgrave Macmillan: New York, NY, USA, 2006; ISBN 978-0-230-62635-5.

37. Wang, H.; Gibson, C.; Zander, U. Editors' Comments: Is Research on Corporate Social Responsibility Undertheorized? Acad. Manag. Rev. 2020, 45, 1-6. [CrossRef]

38. Bansal, P.; Song, H.C. Similar but Not the Same: Differentiating Corporate Sustainability from Corporate Responsibility. Acad. Manag. Ann. 2017, 11, 105-149. [CrossRef]

39. Moratis, L.; Brandt, S. Corporate Stakeholder Responsiveness? Exploring the State and Quality of GRI-Based Stakeholder Engagement Disclosures of European Firms. Corp. Soc. Responsib. Environ. Manag. 2017, 24, 312-325. [CrossRef]

40. Kujala, J.; Rehbein, K.; Toikka, T.; Enroth, J. Researching the Gap between Strategic and Operational Levels of Corporate Responsibility. Balt. J. Manag. 2013, 8, 142-165. [CrossRef]

41. Mirvis, P.; Googins, B. Stages of Corporate Citizenship. Calif. Manag. Rev. 2006, 48, 104-126. [CrossRef]

42. Aggerholm, H.K.; Trapp, N.L. Three Tiers of CSR: An Instructive Means of Understanding and Guiding Contemporary Company Approaches to CSR? Bus. Ethics 2014, 23, 235-247. [CrossRef]

43. Dyllick, T.; Muff, K. Clarifying the Meaning of Sustainable Business: Introducing a Typology From Business-as-Usual to True Business Sustainability. Organ. Environ. 2016, 29, 156-174. [CrossRef]

44. Campbell, J.L. Why Would Corporations Behave in Socially Responsible Ways? An Institutional Theory of Corporate Social Responsibility. Acad. Manag. Rev. 2007, 32, 946-967. [CrossRef]

45. Landrum, N.E. Stages of Corporate Sustainability: Integrating the Strong Sustainability Worldview. Organ. Environ. 2018, 31, 287-313. [CrossRef]

46. Bjørn, A.; Bey, N.; Georg, S.; Røpke, I.; Hauschild, M.Z. Is Earth Recognized as a Finite System in Corporate Responsibility Reporting? J. Clean. Prod. 2017, 163, 106-117. [CrossRef]

47. Sroufe, R. Integration and Organizational Change towards Sustainability. J. Clean. Prod. 2017, 162, 315-329. [CrossRef]

48. Asif, M.; Searcy, C.; Zutshi, A.; Fisscher, O.A. An Integrated Management Systems Approach to Corporate Social Responsibility. J. Clean. Prod. 2013, 56, 7-17. [CrossRef]

49. Lenssen, G.; Tyson, S.; Pickard, S.; Bevan, D.; Aldama, L.R.P.; Amar, P.A.; Trostianki, D.W. Embedding Corporate Responsibility through Effective Organizational Structures. Corp. Gov. Int. J. Bus. Soc. 2009, 9, 506-516. [CrossRef]

50. Spitzeck, H. The Development of Governance Structures for Corporate Responsibility. Corp. Gov. Int. J. Bus. Soc. 2009, 9, 495-505. [CrossRef]

51. Engert, S.; Baumgartner, R.J. Corporate Sustainability Strategy-Bridging the Gap between Formulation and Implementation. J. Clean. Prod. 2016, 113, 822-834. [CrossRef]

52. Lock, I.; Seele, P. CSR Governance and Departmental Organization: A Typology of Best Practices. Corp. Gov. 2016, 16, 211-230. [CrossRef]

53. Wolff, S.; Brönner, M.; Held, M.; Lienkamp, M. Transforming Automotive Companies into Sustainability Leaders: A Concept for Managing Current Challenges. J. Clean. Prod. 2020, 276, 124179. [CrossRef]

54. Tischner, U.; Charter, M. Sustainable Product Design. In Sustainable Solutions: Developing Products and Services for the Future; Routledge: New York, NY, USA, 2017; ISBN 978-1-351-28247-5.

55. Hutchins, M.J.; Sutherland, J.W. An Exploration of Measures of Social Sustainability and Their Application to Supply Chain Decisions. J. Clean. Prod. 2008, 16, 1688-1698. [CrossRef]

56. Gmelin, H.; Seuring, S. Determinants of a Sustainable New Product Development. J. Clean. Prod. 2014, 69, 1-9. [CrossRef]

57. D’Eusanio, M.; Lehmann, A.; Finkbeiner, M.; Petti, L. Social Organizational Life Cycle Assessment: An Approach for Identification of Relevant Subcategories for Wine Production in Italy. Int. J. Life Cycle Assess. 2020, 25, 1119-1132. [CrossRef]

58. Jørgensen, A.; Le Bocq, A.; Nazarkina, L.; Hauschild, M. Methodologies for Social Life Cycle Assessment. Int. J. Life Cycle Assess. 2008, 13, 96-103. [CrossRef] 
59. Weidema, B.P. The Social Footprint-a Practical Approach to Comprehensive and Consistent Social LCA. Int. J. Life Cycle Assess. 2018, 23, 700-709. [CrossRef]

60. Wu, R.; Yang, D.; Chen, J. Social Life Cycle Assessment Revisited. Sustainability 2014, 6, 4200-4226. [CrossRef]

61. Dyllick, T.; Rost, Z. Towards True Product Sustainability. J. Clean. Prod. 2017, 162, 346-360. [CrossRef]

62. Schulte, J.; Hallstedt, S.I. Self-Assessment Method for Sustainability Implementation in Product Innovation. Sustainability 2018, 10, 4336. [CrossRef]

63. Watz, M.; Hallstedt, S.I. Profile Model for Management of Sustainability Integration in Engineering Design Requirements. J. Clean. Prod. 2020, 247, 119155. [CrossRef]

64. Hallstedt, S.I. Sustainability Criteria and Sustainability Compliance Index for Decision Support in Product Development. J. Clean. Prod. 2017, 140, 251-266. [CrossRef]

65. Schulte, J.; Hallstedt, S.I. Company Risk Management in Light of the Sustainability Transition. Sustainability 2018, 10, 4137. [CrossRef]

66. Hallstedt, S.I.; Isaksson, O. Material Criticality Assessment in Early Phases of Sustainable Product Development. J. Clean. Prod. 2017, 161, 40-52. [CrossRef]

67. Baumann, H.; Boons, F.; Bragd, A. Mapping the Green Product Development Field: Engineering, Policy and Business Perspectives. J. Clean. Prod. 2002, 10, 409-425. [CrossRef]

68. Brones, F.; Monteiro De Carvalho, M. From 50 to 1: Integrating Literature toward a Systemic Ecodesign Model. J. Clean. Prod. 2015, 96, 44-57. [CrossRef]

69. Prendeville, S.; Niemczyk, M.; Sanders, C.; Lafond, E.; Elgorriaga, A.; Mayer, S.; Kane, D. Motivations for and Barriers to Ecodesign in Industry. Cardiff UK ENEC. Retrieved Jan. 2013, 22, 2016.

70. Rossi, M.; Germani, M.; Zamagni, A. Review of Ecodesign Methods and Tools. Barriers and Strategies for an Effective Implementation in Industrial Companies. J. Clean. Prod. 2016, 129, 361-373. [CrossRef]

71. Pigosso, D.C.A.; Rozenfeld, H.; McAloone, T.C. Ecodesign Maturity Model: A Management Framework to Support Ecodesign Implementation into Manufacturing Companies. J. Clean. Prod. 2013, 59, 160-173. [CrossRef]

72. Boks, C. The Soft Side of Ecodesign. J. Clean. Prod. 2006, 14, 1346-1356. [CrossRef]

73. Dreyer, L.; Hauschild, M.; Schierbeck, J. A Framework for Social Life Cycle Impact Assessment (10 Pp). Int. J. Life Cycle Assess. 2005, 11, 88-97. [CrossRef]

74. Jørgensen, A. Social LCA — Way Ahead? Int. J. Life Cycle Assess. 2013, 18, 296-299. [CrossRef]

75. UN Global Compact Office. UN Global Compact Global Corporate Sustainability Report. 2013. Available online: https: //www.unglobalcompact.org/library/371 (accessed on 15 December 2021).

76. Nakamba, C.C.; Chan, P.W.; Sharmina, M. How Does Social Sustainability Feature in Studies of Supply Chain Management? A Review and Research Agenda. Supply Chain. Manag. Int. J. 2017, 22, 522-541. [CrossRef]

77. Vargas, J.R.C.; Mantilla, C.E.M. Sustainable Supply Chain Management Capabilities: A Review from the Resource-Based View, the Dynamic Capabilities and Stakeholder Theories. Lat. Am. J. Manag. Sustain. Dev. 2014, 1, 323-343. [CrossRef]

78. Beske, P. Dynamic Capabilities and Sustainable Supply Chain Management. Int. J. Phys. Distrib. Logist. Manag. 2012, 42, 372-387. [CrossRef]

79. Touboulic, A.; Walker, H. Theories in Sustainable Supply Chain Management: A Structured Literature Review. Int. J. Phys. Distrib. Logist. Manag. 2015, 45, 16-42. [CrossRef]

80. Pagell, M.; Shevchenko, A. Why Research in Sustainable Supply Chain Management Should Have No Future. J. Supply Chain. Manag. 2014, 50, 44-55. [CrossRef]

81. Paulraj, A.; Chen, I.J.; Blome, C. Motives and Performance Outcomes of Sustainable Supply Chain Management Practices: A Multi-Theoretical Perspective. J. Bus. Ethics 2017, 145, 239-258. [CrossRef]

82. Carter, C.R.; Washispack, S. Mapping the Path Forward for Sustainable Supply Chain Management: A Review of Reviews. J. Bus. Logist. 2018, 39, 242-247. [CrossRef]

83. Reuter, C.; Foerstl, K.; Hartmann, E.; Blome, C. Sustainable Global Supplier Management: The Role of Dynamic Capabilities in Achieving Competitive Advantage. J. Supply Chain. Manag. 2010, 46, 45-63. [CrossRef]

84. Teece, D.J.; Pisano, G.; Shuen, A. Dynamic Capabilities and Strategic Management. Strateg. Manag. J. 1997, 18, 509-533. [CrossRef]

85. Eisenhardt, K.M.; Martin, J.A. Dynamic Capabilities: What Are They? Strateg. Manag. J. 2000, 21, 1105-1121. [CrossRef]

86. Hong, J.; Zhang, Y.; Ding, M. Sustainable Supply Chain Management Practices, Supply Chain Dynamic Capabilities, and Enterprise Performance. J. Clean. Prod. 2018, 172, 3508-3519. [CrossRef]

87. Beske, P.; Land, A.; Seuring, S. Sustainable Supply Chain Management Practices and Dynamic Capabilities in the Food Industry: A Critical Analysis of the Literature. Intern. J. Prod. Econ. 2014, 152, 131-143. [CrossRef]

88. Byggeth, S.; Hochschorner, E. Handling Trade-Offs in Ecodesign Tools for Sustainable Product Development and Procurement. J. Clean. Prod. 2006, 14, 1420-1430. [CrossRef]

89. Broman, G.I.; Robèrt, K.-H. A Framework for Strategic Sustainable Development. J. Clean. Prod. 2017, 140, 17-31. [CrossRef]

90. Choi, T.Y.; Dooley, K.J.; Rungtusanatham, M. Supply Networks and Complex Adaptive Systems: Control versus Emergence. J. Oper. Manag. 2001, 19, 351-366. [CrossRef]

91. Heikkurinen, P.; Mäkinen, J. Synthesising Corporate Responsibility on Organisational and Societal Levels of Analysis: An Integrative Perspective. J. Bus. Ethics 2018, 149, 589-607. [CrossRef] 
92. Bengtsson, M.; Alfredsson, E.; Cohen, M.; Lorek, S.; Schroeder, P. Transforming Systems of Consumption and Production for Achieving the Sustainable Development Goals: Moving beyond Efficiency. Sustain. Sci. 2018, 13, 1533-1547. [CrossRef]

93. Randers, J.; Rockstrom, J.; Stoknes, P.E. Transformation Is Feasible: How to Achieve the Sustainable Development Goals within Planetary Boundaries; Stockholm Resilience Centre: Stockholm, Sweden, 2018; Available online: https://www.stockholmresilience. org/publications/publications /2018-10-17-transformation-is-feasible---how-to-achieve-the-sustainable--development-goalswithin-planetary-boundaries.html (accessed on 15 December 2021).

94. United Nations. The Sustainable Development Goals Report. Available online: https://sdgs.un.org (accessed on 15 December 2021). 